\title{
KOMPETENSI PEDAGOGIK GURU DALAM MENINGKATKAN MUTU PENDIDIKAN \\ AQIDAH AKHLAK DI MI \\ (Studi kasus pada kelas V MI Panamur Kersamanah Kabupaten Garut)
}

\author{
Muhidin $^{1}$, Mulyasa,E, Fathurrohman, $\mathrm{A}^{2}$ \\ Universitas Islam Nusantara \\ ujangmuhidin30@gmail.com
}

\begin{abstract}
ABSTRAK
Sesuai Undang-Undang Republik Indonesia Nomor 14 Tahun 2005 tentang Guru dan Dosen Pasal 2 ayat (1) menegaskan bahwa guru mempunyai kedudukan sebagai tenaga profesional pada jenjang pendidikan dasar, pendidikan menengah, dan pendidikan anak usia dini pada jalur pendidikan formal yang diangkat sesuai dengan peraturan perundang-undangan. Pada Pasal 4 juga dijelaskan bahwa kedudukan guru sebagai tenaga professional sebagaimana dimaksud dalam Pasal 2 ayat (1) berfungsi untuk meningkatkan martabat dan peran guru sebagai agen pembelajaran berfungsi untuk meningkatkan mutu pendidikan nasional

Dengan demikian, tidak dapat dipungkiri bahwa guru harus memiliki pengetahuan yang luas, menguasai berbagai jenis bahan pembelajaran, menguasai teori dan praktik pendidikan, serta menguasai kurikulum dan metodologi pembelajaran. Kompetensi guru adalah salah satu faktor yang mempengaruhi tercapainya tujuan pembelajaran dan pendidikan di madrasah, namun kompetensi guru tidak berdiri sendiri, tetapi dipengaruhi latar belakang pendidikan, pengalaman mengajar, dan lamanya mengajar. Berangkat dari paradigma tersebut, penelitian ini bertujuan untuk mengetahui kompetensi profesional guru untuk meningkat meningkatkan kualitas pendidikan di Madrasah Ibtidaiyah Panamur Kersamanah. Penelitian ini menggunakan pendekatan kualitatif dengan metode wawancara mendalam dan dokumentasi. Pemeriksaan keabsahan data dilakukan dengan memperpanjang waktu penelitian dan triangulasi. Hasil penelitian menunjukkan bahwa: (1) Profesional guru merupakan salah satu faktor yang sangat penting dalam meningkatkan mutu pendidikan (2) Mutu pembelajaran Pendidikan Agama di Madrasah Ibtidaiyah Panamur Kersamanah diwujudkan dengan penerapan pembelajaran aktif, kreatif, dan menyenangkan serta melalui penelitian studi kasus. (3) Upaya Kepala Madrasah dalam meningkatkan professional guru di Madrasah Ibtidaiyah Panamur Kersamanah adalah dengan meningkatkan kompetensi guru melalui kursus dan diklat, pengadaan sumber dan media Pembelajaran, mengelola lingkungan belajar, penerapan elearning, dan controling (4) Upaya guru Madrasah Ibtidaiyah Panamur Kersamanah dalam meningkatkan profesionalnya dengan mengikuti diklat dan Kelompok Kerja Guru.
\end{abstract}

Kata Kunci: Kompetensi, Pedagogik, Aqidah Akhlak

\section{ABSTRACT}

As per the law of the Republic of Indonesia Number 14 Year 2005 on Teachers and Lectures Article 2 Paragraph (1) Asserts that teachers have tenure as a professional basic education, secondary education, and earlt childhood education in the formal education are appointed in accordance with the regulations legislation. In section 4 also explained that the status of teachers as professionals as defined in article 2 paragraph (1) Serves to enhance the dignity and role of teachers as agent of learning functions to improve the quality of national education.

Thus, it can not be denied that the teacher must have extensive knowledge, mastering different types of learning materials, mastering the theory and practice of educations, as well as master the curriculum and learning methodologies. Competence of teachers is one of the factors that influence the achievement of

\footnotetext{
${ }^{1}$ Mahasiswa Pascasarjana PAI UNINUS

${ }^{2}$ Dosen Pascasarjana PAI UNINUS
} 
learning and education in the Madrasah but the competence of teachers do not stand alone, but is influenced education background, teaching experience, and lenght of teaching. Departing from this paradigm, this study aims to determine the professional competence of teachers to improve quality of education in Madrasah Ibtidaiyah Panamur Kersamanah. This study used a qualitative approach with indepth interviews and documentation. Examination of the validity of data is done by extending the research and triangulation.The results showed that: (1) Professional teachers is one very important factor in improving the quality of educations, (2) Quality of teaching min is realized by the application of active learning, creative, and fun as well as through case study, (3) Principals efforts to improve professional teachers in Madrasah Ibtidaiyah Panamur Kersamanah is to improve the competence of teachers through course and training, procurement sources and media, managing the learning environment, the application of e-learning, and controling, (4) Effort teachers Madrasah Ibtidaiyah Panamur Kersamanah in improving professional training and by following the teacher working group, and create classroom action research.
Keywords:
Competence,
Pedagogical,
Aqidah
Akhlak 


\section{PENDAHULUAN}

Dalam menciptakan mutu pendidikan sosok guru yang mempunyai kualifikasi, kompetensi, dan dedikasi yang tinggi dalam menjalakan tugas profesionalnya sangat dibutuhkan. ${ }^{3}$ Guru merupakan kunci keberhasilan suatu lembaga pendidikan. Baik buruknya prilaku atau tata cara mengajar guru akan sangat mempengruhi citra lembaga pendidikan. Tanpa adanya sumber daya guru yang profesional mutu pendidikan tidak akan meningkat. ${ }^{4}$ Karena dalam pelaksanaan pendidikan sekolah sangat ditekankan adanya peningkatan mutu sebagai jawaban terhadap kebutuhan dan dinamika masyarakat yang sedang berkembang, sehingga peningkatan mutu dapat diwujudkan melalui pelaksanaan pendidikan. Sejalan dengan hal itu seperti yang tertera dalam Undang-Undang RI No. 14 Tahun 2005 Bab II Pasal 2 ayat (1) menyatakan :

"Guru mempunyai kedudukan sebagai tenaga profesiaonal pada jenjang pendidikan dasar, pendidikan menengah, dan pendidikan anak usia dini pada jalur pendidikan formal yang diangkat sesuai dengan peraturan perundang-undangan."

Guru merupakan suatu profesi, yang berarti suatu jabatan yang memerlukan keahlian khusus sebagai guru dan tidak dapat dilakukan oleh sembarang orang diluar bidang pendidikan. ${ }^{6}$ Tugas guru sebagai suatu profesi meliputi mendidik, mengajar dan melatih. Mendidik berarti meneruskan dan mengembangkan nilai-nilai hidup. Mengajar berarti meneruskan dan mengembangkan ilmu pengetahuan dan teknologi, sedangkan melatih berarti mengembangkan keterampilanketerampilan pada peserta didik. ${ }^{7}$

Guru memiliki kualifikasi akademik, kompetensi, sertifikat pendidik, sehat jasmani dan rohani, serta mampu untuk mewujudkan tujuan Pendidikan Nasional. Kompetensi guru meliputi

${ }^{3}$ Kunandar, Guru profesional Implementasi Kurikulum Tngkat Satuan Pendidikan (KTSP) dan Sukses dalam Sertifikasi Guru, (Jakarta: PT. Raja Grafindo Persada, 2008), hal. 40.

4 Buchari Alma, Guru Profesional, (Bandung: Alfabeta, 2009), hal. 123.

${ }^{5}$ Kunandar, Guru profesional Implementasi Kurikulum Tngkat Satuan Pendidikan (KTSP) dan Sukses dalam sertifikasi Guru, (Jakarta: PT. Raja Grafindo Persada, 2008), hal. 134.

${ }^{6}$ Hamzah B Uno, Profesi Kependidikan, (Jakarta Bumi Aksara, 2008), hal. 15.

7 Moh Uzer Usman, Menjadi Guru Profesional, (Bandung: PT. Rosda Karya, 2008), hal. 7 kompetensi pedagogik, kompetensi kepribadian, kompetensi sosial dan kompetensi profesional yang diperoleh melalui pendidikan profesi. ${ }^{8}$ Masalah kompetensi profesional guru merupakan salah satu dari kompetensi yang harus dimiliki oleh setiap guru dalam jenjang pendidikan apapun. ${ }^{9}$

Tugas dan peran guru dari hari kehari semakin berat, seiring dengan perkembangan ilmu pengetahuan dan teknologi yang berkembang dalam masyarakat. Melalui sentuhan guru disekolah, diharapkan mampu menghasilkan peserta didik yang memiliki kompetensi tinggi dan sisp menghadapi tantangan hidup dengan penuh keyakinan dan percaya diri yang tinggi sekarang dan kedepan, sekolah (pendidikan) harus mampu menciptakan mutu pendidikan, baik secara keilmuan (akademis) maupun secara sikap mental. Oleh karena itu, Menurut Louis V gerstner, Jr., dkk, dalam kunandar dibutuhkan sekolah yang unggul yang memiliki ciri-ciri :

(1) Kepala sekolah yang dinamis dan komunikatif dengan kemerdekaan memimpin menuju visi keunggulan pendidikan; (2) memiliki visi, misi dan strategi untuk mencapai tujuan yang telah dirumuskan dengan jelas; (3) guru-guru yang kompeten dan berjiwa kader yang senantiasa bergairah dalam melaksanakan tugas profesionalnya secara inovatif; (4) peserta didik yang sibuk, bergairah, dan bekerja keras dalam mewujudkan prilaku pembelajaran; (5) masyarakat dan orang tua yang berperan serta dalam menunjang pendidikan. ${ }^{10}$

Faktor-faktor lain yang turut berpengaruh terhadap mutu pendidikan, unsur pendidik dan tenaga kependidikan yang ada disekolah harus mendapat pengelolaan dan pengembangan secara optimal. Hal ini sejalan dengan upaya-upaya yang telah dilakukan oleh pemerintah dalam rangka meningkatkan mutu pendidikan dengan dibuatnya berbagai kegiatan yang berkaitan dengan unsur ketenagaan disekolah.

${ }^{8}$ Undang-Undang Republik Indonesia No. 14 Tahun 2005, Tentang Guru dan Dosen, (Bandung: Citra Umbara, 2006), hal 8-9.

9 Oemar Hamalik, Pendidikan Guru Berdasarkan Pendekatan kompetensi, (Jakarta: Bumi Aksara, 2004), hal. 34.

10 Kunandar, Guru profesional

Implementasi Kurikulum Tngkat Satuan

Pendidikan (KTSP) dan Sukses dalam sertifikasi Guru, (Jakarta: PT. Raja Grafindo Persada, 2008), Hal. 37. 
Oleh karena itu, diperlukanlah sosok guru yang mempunyai kualifikasi, kompetensi dan dedikasi yang tinggi dalam menjalankan tugas profesionalnya. Menurut Mulyasa "Peranan guru memiliki posisi sentral dalam proses pembelajaran. Ada tiga faktor yang mempengaruhi implementasi kurikulum, yaitu dukungan kepala sekolah, dukungan rekan sejawat guru, dan dukungan dari dalam guru itu sendiri","11

Peran strategis guru Pendidikan Aqidah Akhlak di Madrasah Ibtidaiyah, dalam proses pembelajarannya adalah dalam kerangka mengembangkan potensi anak didiksehingga mutu pendidikan aqidah akhlak ditentukan oleh profesionalitas guru itu sendiri. Melalui guru-guru professional, maka transformasi nilai dan ilmu pengetahuan berlangsung sebagaimana diharapkan dapat diwujudkan dengan baik. Begitu pula, jika kualitas guru Pendidikan aqidah akhlak rendah maka hasil belajar anak didik juga cenderung kurang memuaskan atau tidak maksimal pencapaiannya. ${ }^{12}$

Masalah kompetensi guru merupakan hal urgen yang harus dimiliki oleh setiap guru dalam jenjang pendidikan apapun. Guru yang terampil mengajar tentu harus pula memiliki pribadi yang baik dan mampu melakukan sosial adjustment dalam masyarakat. Kompetensi guru sangat penting dalam rangka penyusunan kurikulum. ini dikarenakan kurikulum pendidikan haruslah disusun berdasarkan kompetensi yang dimiliki oleh guru.

Berdasarkan urian tersebut, penulis ingin lebih jauh mengetahui mengenai:

1). Bagaimana realitas pendidikan akqidah akhlak di kelas V MI Panamur?

2).Bagaimana upaya guru pendidikan aqidah akhlak dalam membina berbahasa santun kepada siswa kelas V MI Panamur?

3).Bagaimana untuk menjaga kualitas mutu aqidah akhlak di kelas V MI Panamur?

4).Bagaimana faktor yang mendukung dan menghambat program peningkatan mutu pendidikan berbasis madrasah di kelas V MI Panamur?

\section{METODE}

\footnotetext{
11 E. Mulyasa, Implementasi KTSP, Kemandirian Guru dan Kepala Sekolah, Ed. I (Cet.1,

Jakarta: BumiKarsa, 2008), hal. 180.

${ }^{12}$ IskandarAgung, Menghasilkan Guru

Kompeten \& Profesional, (Jakarta: Bee Media

Indonesia, 2012), hal. 1.
}

Penelitian ini dilaksanakan dengan menggunakan pendekatan kualitatif. Metode yang digunakan analisis deskriptif. Penelitian dilakukan pada semester genap tahun pelajaran 2019-2020 di MI Panamur. Informan adalah stakeholder yang ada di MI Panamur, Kepala Madrasah, Komite madrasah, beberapa guru yang mendapat tugas tambahan mengelola madrasah, bidang keuangan, bidang Kurukulum, bidang Kesiswaan dan beberapa wali peserta didik MI Panamur untuk memperkuat hasil penelitian, termasuk dokumen yang terkait dengan kebijakan penyelengaraan pendidikan madrasah ibridaiyah, notulen rapat, profil madrasah, Emis serta dokumen pengelolaan lainnya yang relevan dengan fokus penelitian (mutu pendidikan madrasah).

\section{KAJIAN TEORI}

\section{Kompetensi Paedagogik Guru}

Kompetensi menunjuk kpada penguasaan melakukn suatu hal yang di dapat dari hasil pmbelajaran dan latihan. ${ }^{13}$ Pengertian dan rumusan yang perlu dipahami tentang kompetensi antar lain adalah, sebagai gambaran menampilkan kemampuan secara utuh yang dapat dilihat dan diukur dari perpaduan antara kemampuan dan juga keterampilannya. Sedangkan menurut Peter Salim, kompetensi juga berarti "quality of condition of being legally quikified, eligible, or admissible, yakni kualitas atau keadaan memenuhi syarat atau yang dapat diterima menurut ketentuan hukum."14 Richard mengatakn bahwa, kompetnsi yaitu perilaku yang dapat dlihat dan diamati juga mengacu pada keperluan untuk menuntaskan kegiatan shari-hari.

Sedangkan menurut Slamet PH dalam bukunya Saiful Sagala dengan judul kompetensi pedagogik guru dan tenaga kependidikan serta kompetensi pedagogik meliputi:

a.Berkontribusi dalam pengembangan KTSP yang terkait dengan bidang studi yang diajarkan.

b.Mengembangkan silabus mata pelajaran berdasarkan standar kompetensi (SK) dan kompetensi dasar (KD)
13 E. Mulyasa, Menjadi Guru Profesional, (Bandung: PT Remaja Rosdakarya, 2011), hal. 96.

14 Peter Salim, Standard Indonesia-English Dictionary, .(Jakarta : Modern English Press, 1993), hal. 426. 
c.Menyusun rencana pelaksanaan pembelajaran (RPP) berdasarkan silabus yang telah dikembangkan.

d.Merancang administrasi pembelajaran dan administrasi kelas.

e.Melaksanakan pembelajaran yang pro pembelajaran (aktif, kreatif, inovatif, eksperimentatif, epektif dan menyenangkan.

f. Mengevaluasi hasil belajar peserta didik secara otentik.

g.Membimbing peserta didik dalam bebagai aspek, misalnya pelajaran, kepribadian, bakat, minat dan karir.

h.Mengembangkan profesionallisme diri sebagai guru. ${ }^{15}$

Pada dasarnya, kompetensi yaitu suatu keprofesionalan dan perilaku yang harus dikuasai, dihayati, dan dimiliki oleh guru dan dosen sebagai seperangkat keterampilan, dan kemampuan dalam menjalankan tugasnya.

Selanjutnya kompetensi pedagogik guru aqidah akhlak.dapat dilihat pada Peraturan Menteri Pendidikan Nasional RI No.16 Tahun 2007, sebagaimana tabel berikut:

\begin{tabular}{|c|c|c|}
\hline $\begin{array}{l}\mathbf{N} \\
\mathbf{o}\end{array}$ & $\begin{array}{l}\text { KOMPETENSI } \\
\text { INTI GURU }\end{array}$ & $\begin{array}{l}\text { KOMPETENSI } \\
\text { GURU AQIDAH } \\
\text { AKHLAK } \\
\end{array}$ \\
\hline 1 & $\begin{array}{l}\quad \text { Mata plajaran } \\
\text { yang diampu } \\
\text { didukunng oleh } \\
\text { penguasan materi, } \\
\text { konssep, dan pola } \\
\text { pikr keillmuan }\end{array}$ & \begin{tabular}{l}
\multicolumn{1}{c}{ Materil } \\
dirumuskan sesuai \\
knsep dan struktr pola \\
pkir ilmu-ilmu yang \\
relivan dengan \\
pembelajran Aqidah \\
Akhlak. \\
$\quad$ Matri, konsep dan \\
strukttur ilmu-ilmu \\
diksji sesuai degan \\
pembelajarn Aqidah \\
Akhlak.
\end{tabular} \\
\hline 2 & $\begin{array}{l}\quad \text { Mata pelajaran } \\
\text { dan pengembangan } \\
\text { yang diampu, } \\
\text { dikuasai bersama } \\
\text { kompetnsi dan } \\
\text { kompetensi dasar. } \\
\end{array}$ & $\begin{array}{l}\quad \text { Konpetensi dasar } \\
\text { bidsng studi yang } \\
\text { diiampu, dikuasai } \\
\text { brsama standdar } \\
\text { konpetensi bidang studi } \\
\text { yang diampu. }\end{array}$ \\
\hline 3 & $\begin{array}{l}\quad \text { Matri } \\
\text { pemblajaran yang } \\
\text { diampu } \\
\text { dikembaangkan } \\
\text { dengan berbagai } \\
\text { varriasi. }\end{array}$ & $\begin{array}{l}\text { Materi bidang } \\
\text { stadi yang dimpu } \\
\text { disesualkan dengan } \\
\text { satuan pertumbhan } \\
\text { peseeta didik. } \\
\text { Materi bldang } \\
\text { studi yang diampu }\end{array}$ \\
\hline
\end{tabular}

15 Saiful Sagala, Kompetensi Profesional Guru Dan Tenaga Kependidikan, (Bandung: Alfabeta, 2009), hal. 32

\begin{tabular}{|c|c|c|}
\hline & & $\begin{array}{l}\text { dikelala secara kreatiff } \\
\text { sesuai dengan tiingkat } \\
\text { prtumbuhan psserta } \\
\text { didik. }\end{array}$ \\
\hline 4 & \begin{tabular}{l}
\multicolumn{1}{c}{ Ke } \\
propfesionalan \\
dikembangkan \\
secara berkelanjutan \\
dengan melakukan \\
tindakan reflektif.
\end{tabular} & $\begin{array}{l}\text { Refleksi kinerja } \\
\text { sendiri dikembanggkan } \\
\text { secara terus menerus. } \\
\quad \text { Penigkatan ke } \\
\text { propfesional dilakukan } \\
\text { dengan cara pemanfatan } \\
\text { hasil refleksi. } \\
\quad \text { Penilaiaan } \\
\text { dilakukan dengan } \\
\text { mengkesplorsi kegiatan } \\
\text { dikellas. } \\
\quad \text { Peningkatan } \\
\text { keperofesionalan } \\
\text { dilakukan dengan } \\
\text { memgeksplorasi proces } \\
\text { kgiataan dikelas. } \\
\quad \text { Pningkatan } \\
\text { keperofesionalan } \\
\text { dilakuikan dengan cara } \\
\text { berlajar dari berbagi } \\
\text { sumber sesuai dengan } \\
\text { prkembangan zman. }\end{array}$ \\
\hline 5 & $\begin{array}{l}\quad \text { Meningkatkam } \\
\text { pengenbangan diri } \\
\text { dengan } \\
\text { memanfatkan } \\
\text { teknoloji imformasi } \\
\text { dan kmunikasi. }\end{array}$ & $\begin{array}{l}\text { Mengembamgkan } \\
\text { diri dengn cara } \\
\text { memamfaatka teknologi } \\
\text { informasi dan } \\
\text { kmunikasi. } \\
\quad \text { Menggembangkan } \\
\text { diri dengan } \\
\text { memantafkan tknologi } \\
\text { informasi dan } \\
\text { kmunikasi. }\end{array}$ \\
\hline
\end{tabular}

\section{Kompetensi pedagogik guru aqidah akhlak}

Guru yang profesional adalah guru yang memiliki seperangkat kompetensi (pengetahuan, ketrampilan, dan perilaku) dalam menjalankan tugasnya, guru harus memiliki, menghayati dan menguasai kepedagogikannya. ${ }^{16}$

Pada Peraturan Menteri Agama RI No.16 tahun 2010 tentang manajemen pendidikan agama pada sekolah. Pada pasal 16 ayat (5) disebutkan bahwa:

Yang dimaksud dengan kompetensi profesional pada ayat (1) yaitu:

a. Pola pikir keilmuan Pendidikan Agama Islam disertai dengan penguasaan materi, struktur dan konsep Pendidikan Agama Islam.

b. Kemampuan menguasai standar kompetensi dasar bidang studi Pendidikan Agama Islam.

${ }^{16}$ Ali Mudlofir, Pendidik Profesional, (Jakarta: PT. Raja Grafindo Persada, 2013),hal. 75 
c. Pengembangan materi pembelajaran mata pelajaran pendidikan agama secara kreatif

Pengembangan pedagogikitas secara berkesinambungan dengan menjalankan tindakan levlektif, dan

Berkomunikasi dan mengembangkan diri dengan memanfaatkan teknologi informasi dan komunikasi.

Sebagai guru profesional sudah sepantasnya memiliki keberagaman kemampuan (comppentencies) yang bersifat psikologis, yang meliputi:

1) Kompetensi kognitif (kecakapan ranah cipta)

2) Kompetensi afektif (kecakapan ranah rasa)

3) Kompetensi psikomotor (kecakapan ranah karsa).

Menurut Mulyasa, ruang lingkup kompetensi pedagogik adalah sebagai berikut:

a) Memahami juga bisa menggunakan teori kependidikan baik filosofi, psikologis, sosiologis, dan sebagainya.

b) Memahami serta bisa menggunakan teori belajar sesuai dengan taraf kemampuan peserta didik.

c) Menguasai penanganan dan pengembangan mata pelajaran yang menjadi tanggung jawabnya.

d) Memahami serta bisa melaksanakan teknik pembelajaran yang bervariasi.

e) Menguasai pengembangan juga penggunaan berbagai alat, perangkat dan sumber belajar yang relevan.

f)Menguasai pengorganisasian dan pelaksanaan program pembelajaran.

g) Menguasai pelaksanaan penilaian hasil belajar peserta didik.

h) Mampu mengembangkan budi pekerti peserta didik.17

Dalam penampilan aktual dalam proses belajar mengajar, paling tidak memiliki empat keterampilan yakni kemampuan:

(a) Merancang dan menyusun kegiatan pembelajaran

(b) Menjalankan serta membimbing/mengatur kegiatan pembelaran

17 E. Mulyasa, Standar Kompetensi Sertifikasi Guru, (Bandung: PT. Remaja Rosdakarya, 2007), hal. 135-136. (c) Mengevaluasi perkembangan kegiatan pembelajaran

(d) Menguasai materi pelajaran.

Kemampuan tersebut di atas adalah kemampuan yang seutuhnya harus dimiliki oleh guru profesional.

\section{Mutu Pendidikan}

Ukuran baik atau buruknya sesuatu, kualitas, taraf atau derajat (kecerdasan serta kepandaian), dalam kamus besar bahasa indonesia disebut "mutu". ${ }^{18}$ Sedangkan mutu adalah kemampuan dalam memuaskan sesuatu yang diinginkan serta menunjukan gambaran karakteristik menyeluruh dari barang atau jasa.

Dalam konteks pendidikan, mutu mempunyai arti yang mencakup input, proses dan output pendidikan. ${ }^{19}$ Menurut Rusman, pendidikan yang bermutu saling berkaitan atara proses dan hasil. Akan tetapi, hasil (output) harus dirumuskan terlebih dahulu oleh sekolah, serta harus jelas target yang akan dicaaqidah akhlak setiap tahun atau kurun waktu lainnya, agar tidak menjadi salah arah. ${ }^{20}$ Menurut Hari Sudradjat

"pendidikan yang memiliki kompetensi atau kemampuan itu adalah kemampuan yang bisa dikatakan bermutu, baik kompetensi akademik ataupun kompetensi kejuruan, yang didasari oleh kompetensi personal dan sosial, juga nilai-nilai akhlak mulia, yang keseluruhannya sebagai kecakapan hidup (life skill), pendidikan yang bisa melahirkan manusia.seutuhnya (manusia paripurna) atau manusia dengan pribadi yang integral (integrated personality) mereka yang bisa menggabungkan iman, ilmu, dan amal.,"21

Dari uraian pendapat di atas jelas bahwa mutu pendidikan adalah suatu pilar untuk mengembangkan sumber daya manusia (SDM). Yang mana suatu masa depan bangsa itu terletak pada keberadaan kualitas pendidikan yang

${ }^{18}$ Poewadarminta. W.J.S., Kamus Umum

Bahasa Indonesia, (Jakarta: Balai Pustaka, 2003), hal. 788.

19 Arcaro,S Joremo, Pendidikan Berbasis Mutu, Prinsip-Prinsip Perumusan dan Tata Langkah Penerapan, (Jakarta: Rieneka Cipta, 2005), hal. 85.

${ }^{20}$ Rusman, Manajemen Kurikulum, (Jakarta: Raja Wali Pers, 2009), hal. 555.

21 Hari Suderadjat, Manajemen Peningkatan Mutu Berbasis Sekolah; Peningkatan Mutu Pendidikan Melalui Implementasi KBK, (Bandung: Cipta Lekas Garafika, 2005), hal. 17. 
berada pada masa kini. Suatu pendidikan yang berkualitas akan muncul apabila terdapat manajemen sekolah yang bagus.

\section{HASIL DAN PEMBAHASAN}

Salah satu misi di bidang kurikulum MI Panamur kersamanah Kabupaten Garut adalah mengembangkan sistem pembelajaran scientific. Sementara pendekatan scientific terdapat dalam konsep K-13. Berkenaan dengan perencanaan pembelajaran aqidah akhlak, guru PAI kelas V MI Panamur Kabupaten Garut terlebih dahulu melakukan persiapan. Persiapan yang dilakukan oleh guru PAI kelas V MI Panamur Kabupaten Garut secara garis besar sama dengan perencanaan-perencanaan pada umumnya, yang terdiri dari menyiapkan silabus, RPP, media, metode, bahan ajar, menentukan alokasi waktu, dan sebagainya.

Pada prinsipnya, pengembangan silabus dan RPP dalam K-13 telah disediakan oleh pemerintah, akan tetapi pemerintah juga memberikan kebebasan sepenuhnya kepada para guru untuk mengembangkan silabus dan RPP sesuai dengan kebutuhan dan karakter peserta didik. Hanya saja di dalam silabus dan RPP terdapat kompetensi inti yang telah ditentukan oleh pemerintah dan berhukum paten (tidak bisa dirubah).

MI Panmur Kersamanah Kabupaten Garut sendiri, secara normatif silabus, RPP, dan penilaian telah disediakan oleh pemerintah. Jadi guru sifatnya tinggal melaksanakan, karena segala sesuatu telah disiapkan oleh pemerintah yang terangkum dalam buku guru K-13. Guru hanya mengikuti alur yang ada, yang secara umum sudah disiapkan oleh pemerintah akan tetapi guru juga bisa berinovasi dalam pengembangannya, terutama dari segi metode. Hal ini sesuai dengan temuan penelitian di lapangan ketika melaksanakan penelitian.

Guru merupakan salah satu komponen pendidikan yang sangat berperan dalam meningkatkan kualitas penddikan. Guru juga dalam meningkatkan kompetensi profesionalnya harus mempunyai strategi agar tugasnya berjalan dengan lancar seperti halnya yang peneliti temukan di MI Panamur sebagai berikut:

Realitas pendidikan Aqidah akhlak di MI Panamur.

Realitas pendidikan Aqidah akhlak di kelas V MI Panmur bisa dikatakan sudah bisa mencapai tujuan yang di harapkan karena bisa dilihat dari setiap lulusan yang sebagian besar selalu memiliki nilai yang baik. Ketika guru menjelaskan materi mengenai akhlak kepada mausia, siswa memperhatikan dengan baik. Sesekali guru memberikan stimulus dengan memancing siswa mengenai materi akhlak kepada sesama, dan siswa mampu menjawab dari pertanyaan tersebut meskipun ada juga yang tidak bisa menjawab. Ketika proses pembelajaran, guru sesekali menegur siswa yang berprilaku kurang sopan ketika proses pembelajaran. Guru juga memberikan stimulus kepada siswa agar bersikap aktif dikelas, aktif dalam bertanya ketika belum memahami materi pelajaran. Guru mampu menciptakan suasana yang kondusif, dengan cara guru memperhatikan bagaimana siswa berprilaku dikelas, dan guru sesekali memberikan pertanyaan kepada siswa yang pada saat itu kurang memperhatikan pelajaran dengan tujuan agar siswa tersebut memiliki rasa takut untuk tidak memperhatikan pelajaran, sehingga suasana belajarpun menjadi aktif dan kondusif.

Dari penjelasan tersebut diatas maka dapat dikatakan bahwa dari adanya guru Aqidah akhlak yang memiliki kompetensi profesional, maka akan meningkatkan mutu pembelajaran mata pelajaran Aqidah akhlak bagi siswa. Dari situlah maka akan menghasilkan dampak yang positif bagi siwa dan guru yang ada disekolah.

Upaya guru pendidikan aqdah akhlak dalam membina berbahasa santun kepada siswa/siswi kelas V MI Panmur.

Guru memulai pembelajaran dengan salam pembuka, setelah guru salam dilanjutkan dengan melakukan absensi, dilanjutkan dengan selalu memotivasi peset didik agar selalu berbicara sopan terhadap semua orang, beliau juga memeriksa tugas yang telah diberikan pada pertemuan sebelumnya. Namun, kaitannya dengan RPP yang beliau buat sebelumnya, guru belum merapkan dalam kegiatan pembelajaran dikelas yang sesuai dengan apa yag ada didalam RPP.

Ketika proses pembelajaran berlangsung, guru menyampaikan pembelajaran dengan menggunakan alat pembelajaran berupa buku, spidol, dan papan tulis.

1.Untuk menjaga mutu pendidikan Aqidah akhlak di MI Panamur.

Guru adalah pendidik profesional dengan tugas utama mendidik, mengajar, membimbing, mengrarahkan, melatih, menilai, dan mengevaluasi peserta didik. Pendidik merupakan pihak yang sangat penting dan memiliki peran yang besar untuk mewujudkan tujuan pendidikan, yaitu menciptakan generasi yang cerdas dan berakhlak yang baik. Guru dikatakan profesional apabila memiliki kompetensi guru yang profesional, yaitu memiliki kompetensi pedagogis, kompetensi 
kepribadian, kompetensi sosial, dan kompetensi profesional. Sebagai pendidik yang profesional guru melakukan proses pembelajaran dengan cara dan metode sesuai dengan materi yang akan diajarkan sehingga pembelajaran menjadi bermutu dan tujuan pembelajaran dapat tercapai.

Guru memiliki kompetensi pedagogik adalah yang memiliki kriteria sebagai guru profesional, guru tersebut memiliki kualifikasi akademik dan latar pendidikan yang sesuai dibidangnya, begitu pula kenyataannya untuk guru Aqidah akhlak di MI Panamur Kersamanah Garut merupakan guru yag mempunyai latar belakang pendidikan dari jurusan pendidikan yang sesuai dibidangnya. Yaitu guru Aqidah akhlak adalah guru yang berasal dari latar belakang pendidikan Agama Islam. Sehingga untuk mengajar materi Aqidah akhlak beliau mampu karena memiliki bekal dari bidang akademik yang ditempuhnya.

2.Faktor yang mendukung dan menghambat program peningkatan mutu pendidikan Aqidah akhlak di MI Panamur.

Guru Aqidah akhlak kelas V MI Panamur terlebih dahulu menyiapkan RPP sebagai acuan dalam pelaksanaan pembelajaran, namun dalam penerpannya ketika proses pembelajaran, guru belum bisa menerapkannya sesuai dengan RPP yag dibuat, guru Aqidah akhlak MI Panamur menggunakan metode pembelajaran ketika proses pembelajaran berlangsung, namun dalam penggunaanya belum berpariasi, guru mengikuti pelatihan sebagai cara untuk mengembangkan keprofesiannya sebagai seorang guru. Pelatihan tersebut adalah guru mengikuti program KKG yang didalamnya memberikan pelatihan dalam membuat RPP dan berbagai permasalahan dalam mengajar.

Dalam proses pembelajaran Aqidah akhlak di kelas V MI Panamur, dengan keikut sertaan siswa dalam pembelajaran itu, dan adanya tujuan pembelajaran maka pembelajaran dapat berlangsung secara baik dan akan meningkatkan mutu pembelajaan mapel Aqidah akhlak, karena dalam pembelajaran guru menyampaikan dengan kemampuan profesionalnya dan siswa mampu menerima pelajaran dengan baik tidak hanaya itu guru juga berusaha untuk memberikan stimulus agar siswa mampu aktif dalam pembelajaran, sehingga tujuan pembelajaran dapat tercapai. Dalam mengkatkan mutu pembelajaran tidak hanya guru dan siswa sajalah yang berperan, namun dari pihak-pihak lain juga sangat berperan. Seperti halnya adanya sarana prasarana yang memadai, situasi ataupun keadaan tempat pembelajaran, dan tujuan pembelajaran.
Langkah-langkah guru Aqidah akhlak kelas V MI Panamur dalam upaya meningkatkan mutu pembelajaran menggunakan strategi antara lain:

\section{Strategi Formal}

a. Mengikuti kursus dan pelatihan guru

Guru mengikuti kegiatan Pendidikan dan Pelatihan Tenaga Guru (PPTG). Hal ini dimaksudkan agar guru mampu merespon perubahan dan tututan perkembangan IPTEK dan kemajuan kemasyarakatan, termasuk perubahan sistem pendidikan dan pembelajarn secara mikro.

Di MI Panamur, Bapak/Ibu guru sering mengikuti pelatihan, seminar, diklat dalam rangka meningkatkan prestasi dan wawasan tentang pendidikan. Pelaksanaan penataran dan lokakarya untuk mengembangkan kemampuan guru dalam melaksanakan proses belajar mengajar. Pelaksanaannya dilaksanakan dengan cara mengundang seorang atau beberapa orang ahli sebagai narasumber.

Diklat bisa dalaksanakan dari bilangan jam sampai bilangan bulan sesuai dengan kebutuhan dan keinginan. Diklat dapat diselenggarakan dengan materi sesuai kebutuhan atau keinginan sehingga hampir semua fungsi pendidikan di madrasah dapat di diklatkan anatara lain: manajemen, kepemimpinan, proses belajar mengajar, administrasi, dan lain-lain.

Karena keluwesan diklat hampir pada seluruh aspeknya, diklat sering di jadikan jalan keluar untuk mengatasi masalah kualitas guru di MI Panamur. Catatan yang perlu diungkap agar diklat dapat benar-benar menjadi solusi bagi masalah mutu guru adalah bahwa pelaksanaan diklat hendaknya setia kepada tujuan.

\section{b. Seminar}

Seminar adalah suatu rangkaian kajian yang diikuti oleh suatu kelompok untuk mendiskusikan, membahas dan memperdebatkan suatu masalah yang berhubungan dengan topik. Berkaitan dengan pelaksanaan supervisi, dalam seminar ini dapat dibahas seperti bagaimana menyusun silabus sesuai standar isi, bagaimana mengatasi masalah disiplin sebagai aspek moral madrasah, bagaimana mengatasi anak-anak yang selalu membuat keributan dikelas, dan lain-lain.

Sebuah seminar biasanya memiliki fokus pada suatu topik yang khusus, dimana mereka yang hadir dapat berpartisipasi secara aktif.

Seminar ssering dilaksanakan melalui sebuah dialog dengan seorang moderator seminar, atau melalui sebuah presentasi hasil penelitian dalam bentuk yang lebih formal. Sistem seminar memiliki gagasan untuk mendekatkan pesertanya 
kepada topik yang dibicarakan. Seminar merupakan suatu pembahasan masalah secara ilmiah, walaupun topik yang dibahas adalah masalah sehari-hari. Dalam membahas masalah, tujuannya adalah mencari sesuatu pemecahan masalah. Oleh karena itu seminar selalu diakhiri dengan kesimpulan atau keputusan-keputusan yang merupakan hasil pendapat bersama. Pembahasan seminar berpangkal makalah atau kertas kerja yang telah disusun sebelumnya oleh beberapa pembicara sesuai dengan pokok bahasan yang diminta oleh suatu penyelenggara yang kan dibahas secara teoritis.

Pembahasan dalam sseminar memakan waktu yang lebih lama karena sifatnya yang ilmiah. Apabila para pembicara tidak dapat mengendalikan diri, waktu akan banyak digunakan untuk pembahasan yang kurang pentig. Oleh krena itu dibutuhkan pimpinan kelompok yang menguasai persoalan, sehingga penyimpangan dari pokok persoalan dapat dicegah. Pelaksanaan seminar di MI Panamur dilakukan oleh dua orang yang selalu memberi motivasi kepada guru-guru lainnya yaitu Bapak Aming M Hayat, S.Pd.I selaku Kepala Madrasah dengan orang yang bisa dipercaya dalam hal ini diserah kan kepada bapak Ujang Supriatna, S.Kom.I (waka kurikulum), beliau berdua bersama-sama menyemangati guruguru yang lain.

Dalam meningkatkan kompetensi pedagogikl guru, Kepala Madrasah mendorong guru untuk kreatif, dan inovatif dengan melakukan beberapa pendekatan terhadap guru-guru yang ada di MI Panamur.

a. Mengikuti Progam MGMP (Musyawarah Guru Mata Pelajaran)

Di MI Panamur guru diharuskan mengikuti Musyawarah Guru Mata Pelajaran sama halnya dengan $\mathrm{KKG}$, yang merupakan suatu organisasi guru yang dibentuk untuk menjadi forum komunikasi yang bertujuan untuk memecahkan masalah yang dihadapi guru dalam pelaksanaan tugsnya sehari-hari di lapangan. Guru sangat berterima kasih kepada Bapak Kepala Madrasah karena adanya kegiatan semacam ini. Jadi, kalau mengajar itu tidak tergesa-gesa dan bisa menguasai materi.

Dalam hal ini, ada beberapa tujuan untuk diselenggarakannya MGMP, yaitu:

1) Untuk memotivasi guru guna meningkatkan kemampuan dan keterampilan dalam merencanakan, melaksanakan dan membuat evaluasi program pembelajaran dalam rangka meningkatkan keyakinan diri sebagai guru profesional
2) Untuk meningkatkan kemampuan dan kemahiran guru dalam melaksanakan pembelajarn sehingga dapat menunjang usaha peningkatan dan pemerataan mutu pendidikan.

3) Untuk mendiskusikan permasalahan yang dihadapi dan dialami oleh guru dalam melaksanaka tugas sehari-hari, dan mencari solusi alternatif pemecahannya sesuai dengan karakteristik mata pelajaran masing-masing guru, kondisi sekolah dan lingkungannya.

4) Untuk membantu guru memperoleh informasi teknis edukatif yang berkaitan dengan ilmu pengetahuan dan teknologi, kegiatan kurikulum, metodologi, dan sistem pengujian yang sesuai dengan mata pelajaran yang bersangkutan.

5) Untuk saling berbagi informasi dan pengalaman dari hasil lokakarya, simposium, seminar, diklat, classroom action research, referensi dan lain-lain kegiatan profesional yang dibahas bersma-sama.

c. Strategi Non Formal

a. Kedisiplinan

MI Panamur selalu mengedepankan kedisiplinan baik itu untuk siswa maupun gurunya. Kedisiplinan itu dimulai dari Bapak aming $\mathbf{M}$ Hayat, S.Pd.I yang menjabat sebagai Kepala Madrasah. Dari hasil pengamatan penaliti biasanya datang jam 6.45 lebih pagi dari guru-guru yag lain, dan pulang lebih akhir. Jam masuk sekolah pada jam 7.00 dan selesai pembelajaran pada jam 12.30 WIB, akan tetapi Bapak Aming M Hayat mengambil kebijakan bahwa guru setidaknya datang kira-kira 10 menit sebelum jam pelajaran dimulai, tata tertib ini lebih dikhususkan pada guru yang mengajar pada jam pelajaran pertma.

Karena sikap Bapak Aminng M Hayat, S.Pd.I guru-guru menjadi rajin dan segan jika datangnya terlambat. Kalau ada guru yang tidak masuk mengajar guru tersebut wajib memberi surat izin beserta alasan yang tepat tidak masuk mengajar, dan wajib memberi tugas kepada peserta didik. Jadi meskipun guru tidak hadir, siswa tetap masih bisa melaksanakan proses pembelajaran sebagaimana mestinya. Kedisiplinan tidak hanya ditujukan kepada peserta didik akan tetapi guru juga perlu ditingkatkan kedisiplinannya karena guru sebagai contoh peserta didiknya.

b.Memotivasi Peserta didik

Sebagai guru yang bertanggung jawab terhadap pencapaian tujuan dengan melalui orang lain atau siswa, mereka diharapkan mempunyai kemampuan untuk memotivasi para siswa denngan memahami apa yang menjadi kebutuhan mereka 
dan berusaha menyiapkan alat-alat pemenuhan kebutuhan para siswa maka seorang guru akan dapat mendorong siswanya mencapai tujuan pembelajaran.

Sebagai motivator peserta didik, guru memiliki strategi yang tepat untuk memberikan motivasi kepada peserta didik dalam melakukan brrbagai tugas dan fungsinya motivasi itu dapat ditumbuhkan melalui:

1) Penyediaan Sarana Prasarana yang Memedai

Sarana yang menunjang dan memadai merupakan harapan dari semua sekolah, termasuk harapan dari Kepala Sekolah dan juga guru-guru berusaha utuk memperbaiki sarana yang ada, agar guru merasa nyaman dalam mengajar. Prasarana atau perlengkapan juga merupakan penunjang dalam proses belajar mengajar.MI Panamur salah satu sarana prasarana yang disediakan oleh Kepala Madrasah adalah penyediaan LCD di kelas-kelas, meskipun belum terealisasi seluruhnya, saat ini masih proses pemenuhan LCD ke semua kelas.

2) Disiplin

Profesionalisme pendidikan perlu ditingkatkan, untuk itu Bapak Aming M Hayat berusaha menanamkan kedisiplinan kepada bawahannya. Melalui kedisiplinan ini diharapkan bisa tercapai tujuan secara efektif dan efisien, serta dapat menghasilkan lulusan yang berkualitas.

3) Dorongan

Setiap tenaga kependidikan memiliki karakteristik yang berbeda satu dengan yang lainnya, sehingga memerlukan perhatian dan pelayanan yang khusus pula dari pemimpinnya, agar mereka dapat memanfaatkan waktu untuk meningkatkan profesionalnya. Bapak Aming M Hayat, S.Pd.I memotivsi semua guru untuk terus berkreasi dalam meningkatkan kualitas pembelajaran.

Meningkatkan kompetensi pedagogik guru membutuhkan motivasi dan dukungan dari berbagai pihak seperti halnya motivasi dari Kepala Madrasah. Bapak Aming M Hayat, S.Pd.I sebagai kepala madrasah selalu mendorong atau memberikan motivasi kepada guru-guru untuk lebih kreatif dan inovatif dalam proses pembelajaran di kelas, dengan motivasi dari kepala Madrasah itu, maka guru menjadi semanagat dalam menjalankan tugasnya. Dorongan atau motivasi tidak hanya datang dari kepala Madrasah akan tetapi semua guru juga memotivasi dirinya sendiri untuk meningkatkan profesionalnya.

Strategi dalam pelaksanaan peningkatan kompetensi guru, tidak selamanya ssesuai dengan yang diharapkan, selalu mengalami kendalakendala yang terjadi berdasarkan wawncara dan observasi antara lain:

1.Kendala pada upaya pengembangan kompetensi kurang atau keterbatasan penguasaan IT di Madrasah dan keterbatasan waktu.

Dari hasil wawancara dan observasi yang dilakukan, rata-rata guru MI Panamur meliki kompetensi paedagogik dalam katagori cukup. Satu-satunya kompetensi paedagogik yang dapat dikatagorikan baik adalah pemanfaatan teknologi informasi dan komunikasi dalam proses pembelajaran. Dimensi yag lain yang meliputi: penguasaan karakteristik anak didik, penguasaan teori dan prinsip-prinsip pembelajaran, pengembangan kurikulum mata pelajaran yang diampu, penyelenggaraan pembelajarn yang mendidik, upaya mempasilitasi pengembangan dan pengaktualisasian berbagai potensi yang dimiliki anak didik, kemampuan berkomunikasi yang efektif, empatik dan santun kepada semua anak didik, kemampuan menilai dan mengevaluasi. Sesuai dengan penuturan Bapak Aming M Hayat, S.Pd.I selaku Kepala Madrasah mengatakan, bahwa: "dalam dimensi kompeetensi kepribadian, dikategorikan baik dalam hal patuh pada norma agama, hukum sosial dan kebudayaan nasioanal. Namun rata-rata cukup dalam hal kejujuran, akhlak mulia keteladanan, pribadi yang mantap dll. Sementara dimensi kompetensi sosial para guru, rata-rata meliki skor baik. Antara lain dalam hal: sikap inklusif, bertindak objektif tidak diskriminatif terhadap anak didik, berkomunikasi dan beradaptasi dengan semua lapisan dan tempat bekerja."

Sementara dalam kompetensi profesional, para guru meliki skor baik dalam hal pemanfaatan teknologi informasi dan komunikasi untuk berkomunikasi dan pengembangan diri. Dan hanya berskor cukup dalam hal penguasaan materi, struktur, konsep, pola pikir keilmuan yang mendukung mata pelajaran yang diampu, penguasaan standar kompetensi dan kompetensi dasar mata pelajaran, pengembangan mateeri pembelajaran secara kreatif, dan pengembangan keprofesionalan secara berkelanjutan.

2.Kendala pada upaya pengembangan kompetensi penguasaan materi adalah kurang kreatifnya guru dalam proses pembelajaran di kelas dan kurang banyaknya koleksi buku atau fasilitas sekolah.

Menjadi guru merupakan profesi yang mulia karena seorang guru membutuhkan kesungguhan, keseriusan dan ketulusan pengabdian dari hati dalam mengajar murid- 
muridnya. Seorang guru harus amanah dalam mengemban tugasnya. Seperti namnya, guru, yaitu digugu dan ditiru, yakni seseorang yang dapat memberikan panutan, contoh atau teladan kepada muridnya dengan bersikap arif dan bijaksana. Sehingga mereka harus membimbing dan menuntun untuk menjadikan seorang pintar dan dewasa dalam berpikir dan bertindak. Peran guru harus didasari atas komitmen mendidik dengan tujuan mulia yaitu melahirkan generasi-generasi masa depan yang unggul dan cerah. Karena guru yang cerdas dan kreatif akan melahirkan outfut murid-murid yang cerdas dan kreatif juga.

Oleh karena itu guru harus mampu mengeksplorasi semua potensi dan kemampuan dirinya. Guru harus akrab dengan berbagai sumber keilmuan dan media informasi baik cetak maupun elektronik. Guru berupaya untuk terus bisa mengikuti perkembangan jaman sehingga cakrawala berpikirnnya akan terbuka dan banyak mendapatkan informasi sehingga menambah wacana untuk melakukan suatu aktifitas pembelajaran yang kreatif dan inovatif.

3.Secara administrasi pendidikan kurang adanya hasil karya ilmiah yang dibuat oleh guruguru.

Aktivitas sebagai guru di MI Panamur belum berubah, terjebak rutinitas, pagi datang hingga siang pulang. Guru mengajar seperti biasa meggunakan metode cermah. Andalan utama guru adalah buku teks. Akibatnya proses pengajaran tidak merangsang peserta didik untuk membaca lebih dalam dari informasi guru. Pemandangan semacam ini mestinya dapat diatasi, jika guru lebih sensitif dengan kondisi anak. Serta adanya kemauan dan kemampuan guru untuk mecari tahu kemapuan dan kemauan peserta didik.

Melalui penelitian tindakan kelas misalnya, memungkinkan seorang guru mengetahui efektivitas pembelajaran, mecari cara-cara untuk meningkatkan, serta memilih metode mengajar yang efektif. Namun riset dikalangan guru belum menjadi tradisi keilmuan, dikalangan guru masih banyak terdengar bahwa penelitian tindakan kelas itu dibuat sekedar untuk memenuhi persyaratan sertifikasi atau kenaikan pangkat.

Ada sebagian guru di MI Panamur, membuat karya penelitian itu hanya karena memenuhi persyaratan sertifikasi atau kenaikan pangkat. Praktis, karya ilmiah itu dibuat sekedarnya dan tidak maksimal. Selanjutnya, selain mentalitas, faktor lainnya adalah kemampuan. Ketika seorang guru harus menyusun laporan penelitian, berarti dia harus memiliki kemampuan menulis dan kemampuan meneliti.
Dalam hal kemampuan menulis, ternyata tidak semua guru memiliki kemampuan itu. Sebab musababnya karena sebagian guru relatif jarang membaca. 


\section{PENUTUP}

1. Realitas Pendidikan Aqidah akhlak di kls V MI Panamur bisa dikatakan sudah sesuai dengan harapan, karena setiap lulusan sebagian besar selalu mendapat nilai yang baik serta bisa dilihat dari perilku siswa yang memiliki akhlakul kareemah.

2. Upaya guru pendidikan aqidah akhlak dalam membina berbahasa santun kepada siswa kelas V MI panamur, guru mengawali pembelajaran dengan salam pembuka, dilanjutkan dengan absensi, dan guru memberikan motivasi kepada siswa mengenai pentingnya belajar, serta guru selalu memotivasi agar selalu berbicara sopan santun terhadap semua orang, beliau juga memeriksa tugas yang telah diberikan pada pertemuan sebelumnya.

3. Untuk menjaga mutu pendidikan aqidah akhlak di kelas V MI Panamur, guru mengikuti pelatihan sebagai cara untuk mengembangkan keprofesionalannya seagai seorang guru. Pelatihan tersebut adalah guru mengikuti program KKG yang didalamnya memberikan pelatihan dalam membuat RPP dan bebagai permasalahan dalam mengajar.

4. Faktor yang mendukung program peningkatan mutu pendidikan aqidah akhlak di MI Panamur adalah, kedisiplinan yang diterapkan oleh semua guru dan siswa MI Panamur, akhlak mulia yang telah tertanam di jiwa guru dan siswa MI Panamur, motivasi yang dimiliki oleh siswa dalam belajar sehingga siswa mudah mencapai nilai kelulusan yang ditentukan oleh sekolah dan keilmuan yang dimiliki oleh guru aqidah akhlak. Serta dengan selalu mengadakan pelatihan yang diikuti oleh guru aqidah akhlak setiap satu bulan sekali yang diselenggarakan oleh MI Panamur Kersamanah Kabupaten Garut.

Sedangkan hal yang menghambat adalah, bahwa belum ada pelatihan pengajaran bagi guru yang khusus diberikan kepada guru mata pelajaran aqidah akhlak, belum maksimalnya penggunaan alat atau media pembelajaran yang diterapkan ketika proses belajar mengajar berlangsung, karena minimnya jumlah media tersebut, kurangnya strategi pembelajaran yang dimiliki guru, belum diterapkannya pembelajaran yang sesuai dengan RPP yang telah dibuat sebelumnya, disamping itu pula masih kurangnya kesadaran bagi siswa untuk belajar aktif ketika proses pembelajaran berlangsung.

Sebagai tindak lanjut dari beberapa temuan penelitian, maka peneliti merekomendasikan dalam bentuk saran terkait strategi guru Aqidah akhlak dalam mengembangkan kompetensi profesionalnya.

1. Guru diharapkan untuk lebih meningkatkan kompetensi profesionalnya dalam proses belajar mengajar di sekolah/madasah, karena ilmu pengetahuan dan teknologi terus berkembang, agar proses belajar mengajar tidak menjenuhkan atau monoton dan menghasilkan lulusan yang berkualitas.

2. Guru diharapkan untuk lebih giat mempelajari perkembangan ilmu pengetahuan dan teknologi, meningkatkan kualitas diri dengan terus belajar sebelum memberikan materi di kelas, seorang guru hendaknya memahami secara baik seluk beluk dunia pendidikan dan permasalahanpermasalahan yang sedang dihadapi dunia pendidikan di Indonesia saat ini.

3. Bagi peneliti lanjutan, diharpkan hasil penelitian ini dapat dijadikan referensi, serta diharapkan dapat dilakukan penelitian lebih lanjut dan mendalam tentang strategi guru PAI dalam mengembangkan profesionalnya yang dirasa masih perlu perbaikan dan penelitian yang berkelanjutan dengan fokus lain, sebab dalam penelitian ini masih banyak keterbatasan dan kekurangan.

4. Penelitian ini dapat dikembangkan untuk penelitian selanjutnya dengan menggunakan data lebih lengkap baik dari lingkungan internal maupun eksternal dan memperbanyak jumlah informan serta melibatkan informan dari direktorat sesuai dengan struktur organisasi agar dapat dianalisis lebih mendalam. 


\section{DAFTAR PUSTAKA}

Buchari, Guru Profesional, (Bandung: Alfabeta, 2009), hal. 123. hal. 788 .

Hamalik, Pendidikan Guru Berdasarkan Pendekatan kompetensi, (Jakarta: Bumi Aksara, 2004), hal. 34.

Iskandar, A. Menghasilkan Guru Kompeten \& Profesional, (Jakarta: Bee MediaIndonesia, 2012), hal. 1.

Joremo, Pendidikan Berbasis Mutu, Prinsip-Prinsip Perumusan dan Tata Langkah Penerapan, (Jakarta: Rieneka Cipta, 2005), hal. 85.

Kunandar, Guru profesional Implementasi Kurikulum Tngkat Satuan Pendidikan (KTSP) dan Sukses dalam Sertifikasi Guru, (Jakarta: PT. Raja Grafindo Persada, 2008),

Mudlofir, Pendidik Profesional, (Jakarta: PT. Raja Grafindo Persada, 2013), hal. 75.

Mulyasa, Implementasi KTSP, Kemandirian Guru dan Kepala Sekolah, Ed. I (Cet.1, Jakarta: BumiKarsa, 2008), hal. 180 .

Mulyasa, Menjadi Guru Profesional, (Bandung: PT Remaja Rosdakarya, 2011), hal. 96.

Poewadarminta., Kamus Umum Bahasa Indonesia, (Jakarta: Balai Pustaka, 2003),

Rusman, Manajemen Kurikulum, (Jakarta: Raja Wali Pers, 2009), hal. 555.

Sagala, Kompetensi Profesional Guru Dan Tenaga Kependidikan, (Bandung: Alfabeta, 2009), hal. 32

Salim, Standard Indonesia-English Dictionary, .(Jakarta : Modern English Press, 1993), hal. 426.

Suderadjat, Manajemen Peningkatan Mutu Berbasis Sekolah; Peningkatan Mutu
Pendidikan Melalui Implementasi KBK, (Bandung: Cipta Lekas Garafika, 2005), hal. 17.

Undang-Undang Republik Indonesia No. 14 Tahun 2005, Tentang Guru dan Dosen, (Bandung: Citra Umbara, 2006), hal 8-9.

Uno, B. Profesi Kependidikan, (Jakarta Bumi Aksara, 2008), hal. 15.

Usman, Menjadi Guru Profesional, (Bandung: PT. Rosda Karya, 2008), hal. 7 